\title{
THE PRODUCT CYCLE AND HIGH TECHNOLOGY INDUSTRY IN NONMETROPOLITAN AREAS, 1976-1980
}

\author{
James P. Miller*
}

\section{Introduction}

Many communities in nonmetropolitan America will face long-term economic decline because of powerful global and technological forces unless they can find new sources of growth. Jobs and incomes have been lost irretrievably in long-established rural industries such as agriculture, forestry, mining, and low-wage, low-technology manufacturing. Survival and growth of rural communities has and will continue to depend on their ability to attract new businesses and industries. The immediate question is: what kinds of new business activity are rural areas most likely to attract? Some policymakers and local officials believe that rural areas should attempt to encourage investment in fast-growing high technology industries because these industries are clean and are perceived to provide stable jobs at high wages.

States and communities are committing an increasingly larger share of their scarce economic development resources to high technology development programs. A recent congressional report (U. S. Congress, 1982) lists 38 programs in 22 states specifically targeted to high-tech industries. Specific programs include joint research and development partnerships among government, industry and universities; physical incubator facilities; venturecapital assistance; entrepreneurial job training for workers; technology transfer programs; and tax and regulatory incentives.

To evaluate the potential effectiveness of high-tech industrial development programs, state and local officials need information on how these industries have been performing in rural America in recent years. In particular, they need to know how much employment high-tech firms have been generating in nonmetropolitan areas and whether high-tech firms are up-grading the quality of local jobs and improving the industrial structure of rural economies.

This report examines the degree and manner in which nonmetropolitan areas are participating in the burgeoning national expansion of high technology industries. It focuses on the locational orientation and ownership distribution of employment created by new business establishments during 1976-80. The argument of the report is

"Economist, Agricultural and Rural Economics Division, Economic Research Service, U.S. Department of Agriculture simple. It reduces to the proposition, derived from product cycle theory, that relatively few high-tech, manufacturing establishments locate in nonmetropolitan areas and that those that do generally are routine assembly operations owned and controlled by corporations headquartered in other regions.

\section{Review of the Literature on the Product Cycle High-Tech Location}

The effect of the product cycle on the locational orientation of high-tech industries has been well-documented in several recent studies. ${ }^{1}$ Armington, Odle and Harris (1983), Herzog, Schlottman and Johnson (1986), Markusen, Hall and Glasmeier(1986), Massey and Meegan (1982), Suarez-Villa (1984), Sveikauskas (1979), and Thomas (1975) have shown consistently that firms in the initial stages of product development and innovation, tend to cluster in or near large metropolitan areas where they can find technical and professional workers and support services. Sveikauskas, for example, also has shown that the incidence of new high-tech firms and employment increases with the size of the urban area and the availability of technical and professional workers. Other studies, by Park and Wheeler (1983) and Smith and Barkley (1988), have demonstrated that nonmetropolitan areas have a comparative advantage for only the more standardized portions of the production process in high technology industries, activities that characterize the third phase of the product cycle. As high-tech firms enter the third stage of the product cycle, they transfer their more routine production activities to affiliates in nonmetropolitan areas. The rate at which high tech jobs "filter-down" to nonmetropolitan areas thus depends on where the high-tech firms are in the product cycle. When a large proportion of high-tech industries are entering stage three, employment growth prospects are favorable for nonmetropolitan areas.

As they adjust to the final stage of their product cycles, national corporations have perpetuated a "spatial division of labor" that generally has separated high-skilled, high-wage administrative and innovative jobs in urban areas from low-skilled, low-wage jobs in standardized production activities in outlying areas. Hansen (1979) and Jacobs (1984) observing this trend in the South, particularly in the nonmetropolitan areas of the South, conclude 
that the region has become a vulnerable branch plant economy. Foreign competition has forced many corporations, especially those with headquarters located outside the South, either to shut down or shift production activities to foreign locations where wages are even lower than in the South. Manufacturing branch operations located in nonmetropolitan areas, according to Erickson (1976), are more adversely affected during periods of slumping demand than are metropolitan plants. Parent organizations are likely to curtail production at their marginal fabrication and assembly plants in rural areas before they do in their urban-based operations.

Three recent empirical studies have examined the effect of the product cycle on ownership and the decentralization of high technology industries. Barkley (1988) and Smith and Barkley (1988) found that while nonmetropolitan employment in the high technology sector increased as a result of decentralization, most of the jobs were in routine production branch plants that pay low wages. ${ }^{2}$ High technology manufacturers in the innovative stages of their product cycles were reluctant to shift production activities to nonmetropolitan areas distant from large urban research centers. Malecki (1985), in a study of corporate organization and its effect on high tech location discovered that nearly 60 percent of the employment of new business operations in four high-technology industries (computers, semiconductors, medical instruments and computer programming) was created by corporate branch plants. Branch plants that were nonregionally owned and controlled accounted for nearly 50 percent of the employment. Hightech corporations, according to Malecki, are more inclined to open branches in other regions after they have gone through the initial stages of product development and mass production in the home region. In the third stage of the product cycle, competition in the industry intensifies and firms seek to reduce labor costs by shifting routine production out of the home region to areas in other regions with plentiful low-wage unskilled labor. In the earlier stages of the product cycle, the dispersal of branch plants is more likely to beconfined to sites within the same region.

\section{Basic Approach and Data}

The descriptive analysis in this article differs from earlier work on high-tech location in three ways. First, it is based on more comprehensive data and focuses on nonmetropolitan counties. Previous studies either have not examined the ownership characteristics of high-tech firms at the county level or have limited the analysis to a single State or region. Barkley (1988), for example, focused on nonmetropolitan counties for the nation as a whole, but did not examine the ownership characteristics of high tech firms. Second, the study focuses on new, hightech formations. Data on new installations (and expansions) are more likely to reflect recent location decisions and regional comparative advantage than are data for all establishments that could be biased by location decisions made by older firms in earlier periods under different economic conditions. ${ }^{3} \mathrm{New}$ independent businesses also are more likely to represent the early phase of the industrial product cycle in which innovative and nonstandardized production occurs. Finally, the study compares nonregionally-owned, multi-unit affiliates (branch establishments) with regionally-owned affiliates and independent (locallyowned) establishments. Most of the previous studies of high-tech plant location (cited above) have not focused on ownership and the level of external control by national corporations, and this may limit their usefulness for understanding the rural growth process and for formulating rural industrial policy.

\section{Identifying High-Tech Industries.}

"High-tech" is a term commonly used in several contexts in both professional and popular literature. In most previous studies, industries were considered to be high-tech if:

- research and development expenditures were a high percentage of gross sales, and

- scientists, engineers and technicians made up a high percentage of their workforce.

The definition used in this study is based on the work of Armington, Harris and Odle (1983) and Rich, Hecker and Burgan (1983). An industry is classified as "hightechnology" if more than 8 percent of its employees are in scientific, engineering and technical occupations and at least 5 percent of them are in scientific and engineering categories, or if expenditures for research and development (R\&D) are a relatively large percentage of product sales (twice the average for all industries). ${ }^{4}$ At the 3-digit standard industrial classification (SIC) level, 29 SICs were identified as high-tech industries (Table 1). Of this group, six manufacturing industries and three business service industries were classified as high R\&D industries. The rest of the industries in manufacturing (SIC 20-39) and the business services (SIC 73) sectors were judged to be in the "low technology" category.

\section{USEEM Data}

The data for new establishments were extracted from a larger data file-U.S. Establishment and Enterprise Microdata (USEEM) - developed by The Brookings Institution under contract with the U.S. Small Business Ad- 
Table One

High Technology Industries*

\begin{tabular}{|c|c|}
\hline SIC & Industry \\
\hline 131 & Crude Petroleum and Natural Gas \\
\hline 132 & Natural Gas Liquids \\
\hline 281 & Industrial Inorganic Chemicals \\
\hline 282 & Plastics Materials, Synthetic Resins and other Man-made Fibers \\
\hline $283^{* *}$ & Drugs \\
\hline 286 & Industrial Organic Chemicals \\
\hline 289 & Miscellaneous Chemical Products \\
\hline 291 & Petroleum Refining \\
\hline 348 & Ordnance and Accessories \\
\hline 351 & Engines and Turbines \\
\hline 353 & Construction/Mining, Machinery and Equipment \\
\hline 356 & General Industrial Machinery and Equipment \\
\hline $357^{* *}$ & Office Computing and Accounting Machines \\
\hline 362 & Electrical Industrial Apparatus \\
\hline 365 & Radio and Television Equipment except Communication Types \\
\hline $366^{* *}$ & Communication Equipment \\
\hline $367^{* *}$ & Electronic Components and Accessories \\
\hline $372^{* *}$ & Aircraft and Parts \\
\hline $376^{\circ *}$ & Guided Missles and Parts \\
\hline 381 & Engineering, Lab and Science Research Instruments \\
\hline 382 & Measuring and Controlling Instruments \\
\hline 383 & Optical Instruments and Lenses \\
\hline 384 & Surgical, Medical, Dental, Instruments and Supplies \\
\hline 385 & Ophthalmic Goods \\
\hline 386 & Photographic Equipment and Supplies \\
\hline 387 & Watches, Clocks \\
\hline \multicolumn{2}{|c|}{ Business Services: } \\
\hline $737^{* *}$ & Computer and Data Processing Services \\
\hline $739^{* *}$ & Research and Development Labs, Testing Labs \\
\hline 892 & Non-commercial Educational and Science Research Organizations \\
\hline \multicolumn{2}{|c|}{ Other (Non-high Technology) Categories: } \\
\hline \multicolumn{2}{|c|}{ Low Technology Manufacturing and Business Services" } \\
\hline \multicolumn{2}{|c|}{ Other Industries } \\
\hline
\end{tabular}

\footnotetext{
- This list of 29 high technology industries was derived from a list compiled by The Brookings Institution for a study of high technology industry (Armington, Harris and Odle, 1983). Two criteria were used to select high technology industries at the 3 digit standard industrial classification (SIC) level: the proportion of total industry work force in scientific and technical jobs (e.g., engineers, life and physical scientists, engineering and science technicians, and computer specialists) and the ratio of research and development expenditure to sales.

- This group comprises industries with a ratio of research and development (R\&D) expenditures to sales at least twice the average for all industries. The six manufacturing industries were classified as "high R\&D" industries by researchers at the Bureau of Labor Statistics (BLS) for a previous study (Burgan, 1985). The three business services industries were added to the BLS list as "high R\&D" activities that typically support the manufacturing sector.

- Refers to all activity in the manufacturing and business services sectors that is not classified, "high technology."
} 
ministration (Armington, Harris and Odle, 1983). The USEEM database contains microdata records on about 1.4 million new client firms of the Dun and Bradstreet creditrating services between 1976 and $1980 .^{5}$

The file includes nearly all nonfarm businesses with employees. Its principal advantage over census and administrative sources is that the data for each firm are constructed in a corporate "family tree" that allows researchers to identify firm status as an affiliate within a multi-locational corporation with headquarters either in the same census region or with headquarters outside the census region, or as an independent, single-location firm.

Onelimitation of this study is that the period, 197680 , may not be sufficiently up-to-date to reflect fully the current locational pattern and ownership structure of hightech employment. Much of the high-tech growth in nonmetropolitan areas in the late 1970s was energy-related, whereas growth since 1980 has been primarily in defenserelated computer manufacturing, data processing services, and consumer electronic products. The pattern of ownership and location in the late 1970s, however, should approximate the pattern in the 1980 s. The locational tendencies of different ownership categories of firms are not likely to change much over such a short period.

\section{Location Quotients}

Employment location quotients are used in Tables 3 and 5 to measure the locational orientation of various categories of industries. They are based on employment in new establishment formations. Location quotients approximately indicate the level of metropolitan-nonmetropolitan specialization in these industries. A location quotient greater than 1 shows that a group of counties (metropolitan or nonmetropolitan) in a census division specializes in a particular industry category and that it markets (exports) some of the product or service outside the area. A quotient less than 1 suggests that the industry is underrepresented in the counties and that the product or service is imported. The main advantage of location quotients is that they prevent the classifying of an area (e.g., the metropolitan portion of New England) as a high tech agglomeration simply because it has a large number of jobs in new high tech formations. ${ }^{6}$

\section{Empirical Results}

If it is true, as product cycle theory indicates, that innovative, high-tech industries and firms require urban agglomeration economies in the early stages of growth, then new, high-tech establishments should account for a larger share of the employment created in metropolitan than nonmetropolitan areas. The tendency for new hightech establishments to locate in metropolitan areas is evident in Table 2. New high-tech establishments created approximately 1.1 million jobs in 1976-1980, about 8.8 percent of the total employment created by all new establishments in metropolitan areas. In nonmetropolitan areas, the high-tech share was only 5.4 percent. In the more innovative, "high R\&D" industries (computer manufacturing and computer software), new establishments created about 5.4 percent of the total employment in metropolitan areas, three times the percentage in nonmetropolitan areas.

\section{Locational Orientation}

Metropolitan areas stand out as the preferred location of high-tech industries. As shown by location quotients greater than 1 (Table 3 ), new jobs created by hightech industries were more concentrated in metropolitan than in nonmetropolitan counties. In five of the nine U.S. census divisions, the location quotient exceeded 1 in metropolitan areas (and was less than 1 in nonmetropolitan areas), and in two of the remaining four divisions, the location quotient, though less than 1 , was higher in metropolitan than in nonmetropolitan areas. High-tech jobs in new establishments were concentrated in nonmetropolitan counties only in the East North Central division where many nonmetropolitan counties are within commuting distance of major metropolitan manufacturing areas.

Innovative, high R\&D industries appeared to be even more oriented to metropolitan areas than the broad category of high-tech industry. Location quotients for high $R \& D$ industries exceeded those for high-tech as a whole in six of nine census divisions (Table 3 ). In nonmetropolitan areas, location quotients were less than 1 in all divisions.

Computer manufacturing and software industries showed the strongest tendency among high R\&D industries to agglomerate in metropolitan areas. New computer manufacturing establishments tended to locate in metropolitan areas, primarily in the Northeast and West. They were poorly represented in nonmetropolitan areas of every census division except New England, where many nonmetropolitan areas are highly integrated with metropolitan areas.

The computer software industry also is strongly oriented to metropolitan areas but more regionally dispersed than computer manufacturing. Metropolitan location quotients for computer software were greater than one in seven of the nine census divisions.

Low-tech industries showed a stronger tendency to locate in nonmetropolitan than in metropolitan areas. Location quotients for these industries-the category most 
Table 2

Employment created by new establishments in selected groups of industries in metropolitan and nonmetropolitan areas, $1976-80^{1}$

\begin{tabular}{|c|c|c|c|c|c|c|}
\hline \multirow{2}{*}{ Industry Group ${ }^{2}$} & \multicolumn{2}{|c|}{ Metropolitan } & \multicolumn{2}{|c|}{ Nonmetropolitan } & \multicolumn{2}{|c|}{ United States } \\
\hline & Number & Share & Number & Share & Number & Share \\
\hline & Thou. & Pct. & Thou. & Pct. & Thou. & Pct. \\
\hline High Technology & 1,144 & 8.8 & 195 & 5.4 & 1,339 & 8.1 \\
\hline High R\&D & 706 & 5.4 & 63 & 1.8 & 769 & 4.6 \\
\hline Computer mfg. ${ }^{3}$ & 77 & 0.6 & 4 & 0.1 & 81 & 0.5 \\
\hline Computer services ${ }^{4}$ & 154 & 1.2 & 8 & 0.2 & 162 & 1.0 \\
\hline Other & 475 & 3.6 & 51 & 1.5 & 526 & 3.1 \\
\hline Low technology & 3,033 & 23.4 & 931 & 25.9 & 3,964 & 23.9 \\
\hline Other industry ${ }^{5}$ & 8,799 & 67.8 & 2,462 & 68.6 & 11,261 & 68.0 \\
\hline Total & 12,977 & 100.0 & 3,588 & 100.0 & 16,565 & 100.0 \\
\hline
\end{tabular}

${ }^{1}$ Detail for number of jobs and shares of jobs may not add exactly to totals due to rounding.

${ }^{2}$ See Table 1 for industries in each industry group.

${ }^{3}$ SIC 357

${ }^{4}$ SIC 737

${ }^{5}$ Refers to all other goods- and services-producing industries ( 3 digit SICs) that are not classified as high-and low-technology industries.

Source: U.S. Establishment and Enterprise Microdata, U.S. Small Business Administration.

likely to include non-innovative, routine production activities-were greater than one in the nonmetropolitan portions of four of the nine census divisions. For metropolitan areas, the location quotients were greater than 1 in only two divisions.

\section{Ownership Structure}

The ownership structure of new high-tech establishments in nonmetropolitan areas exhibits two main patterns (Table 4). First, corporate affiliates were the dominant form of new business activity. They accounted for about 88 percent of the jobs in high-tech industries, 80 percent of the jobs in low-tech industries, and 58 percent in other industries. Or put in a more interesting way, locally owned, independent firms, where innovation and new product development are most likely to occur, accounted for only about 11 percent of all jobs created by new high-tech firms in nonmetropolitan areas of the United States. Second, most of the jobs created by new high-tech firms in nonmetropolitan areas were controlled by nonregional corporations. New affiliates with headquarters located outside their census regions accounted for about 58 percent of the jobs created by new, high-tech firms in nonmetropolitan areas, compared with 45 percent in metropolitan areas. Nonregional control of employment was unexpectedly lower in low-tech than in high-tech industries in both nonmetropolitan (42 percent) and metropolitan (32 percent) areas.

A more detailed account of high-tech ownership in nonmetropolitan areas by census division can be seen in Figure 1. The data indicate that nonregionally-owned affiliates were the primary source of new-high tech employment in five of the nine census divisions. They accounted for 77 percent of the employment in new hightech establishments in the East South Central States, 72 percent in the South Atlantic States, 68 percent in the East North Central division, 59 percent in the Mountain division and 51 percent in the West North Central division. Regional affiliates were the leading source of jobs in the four regions where high-tech headquarters tend to concentrate-the Mid Atlantic, West South Central, New England and Pacific census divisions.

\section{Industry Differences}

Nonmetropolitan areas appeared to have a comparative advantage in high technology industries dependent on natural resources, defense expenditures, low-wage labor or noxious production. Location quotients for the nonmetropolitan portions of the census divisions were consistently greater than 1 in the production of chemical products, petroleum, ordnance, radios and TVs, and electrical apparatus (Table 5). 
Table 3

Employment and Location Quotients (LQs) for Employment Created by New Establishments in Selected Groups of Industries, by Census Division, Metropitan and Nonmetropolitan Counties, 1976-801

\begin{tabular}{|c|c|c|c|c|c|c|c|c|c|c|c|}
\hline \multirow{3}{*}{$\begin{array}{c}\text { County and } \\
\text { Census Division }\end{array}$} & \multicolumn{10}{|c|}{ Employment by Industry Group ${ }^{2}$} & \multirow{3}{*}{$\begin{array}{c}\text { Total } \\
\text { Employ- } \\
\text { ment } \\
\text { Number } \\
\text { (Thou.) }\end{array}$} \\
\hline & \multicolumn{2}{|c|}{$\begin{array}{c}\text { High } \\
\text { Technology }\end{array}$} & \multicolumn{2}{|c|}{ High R\&D } & \multicolumn{2}{|c|}{$\begin{array}{l}\text { Computer } \\
\text { Manfacturing } \\
\text { (SIC357) }\end{array}$} & \multicolumn{2}{|c|}{$\begin{array}{l}\text { Computer } \\
\text { Services } \\
\text { (SIC357) }\end{array}$} & \multicolumn{2}{|c|}{$\begin{array}{c}\text { Low } \\
\text { Technology }\end{array}$} & \\
\hline & $\begin{array}{l}\text { Share } \\
\%\end{array}$ & $\begin{array}{c}\mathrm{LQ}^{3} \\
\#\end{array}$ & $\begin{array}{l}\text { Share } \\
\%\end{array}$ & $\begin{array}{c}\mathrm{LQ}^{4} \\
\#\end{array}$ & $\begin{array}{c}\text { Share } \\
\%\end{array}$ & $\begin{array}{c}\mathrm{LQ}^{5} \\
\#\end{array}$ & $\begin{array}{c}\text { Share } \\
\%\end{array}$ & $\begin{array}{c}\mathrm{LQ}^{6} \\
\#\end{array}$ & $\begin{array}{l}\text { Share } \\
\%\end{array}$ & $\begin{array}{c}\mathrm{LQ}^{7} \\
\#\end{array}$ & \\
\hline Metropolitan & 85.4 & 1.09 & 91.8 & 1.17 & 94.7 & 1.21 & 95.1 & 1.21 & 76.6 & 0.98 & 12,977 \\
\hline New England & 7.8 & 1.88 & 8.6 & 2.05 & 17.4 & 4.14 & 6.7 & 1.59 & 4.2 & 1.00 & 689 \\
\hline Middle Atlantic & 10.7 & 0.89 & 12.2 & 1.03 & 16.2 & 1.40 & 16.7 & 1.41 & 13.9 & 1.18 & 1962 \\
\hline East North Central & 12.9 & 0.94 & 10.7 & 0.78 & 11.1 & 0.80 & 15.8 & 1.15 & 16.6 & 1.21 & 2008 \\
\hline West North Central & 4.8 & 1.02 & 5.2 & 1.11 & 1.2 & 0.30 & 5.6 & 1.19 & 3.9 & 0.83 & 774 \\
\hline South Atlantic & 12.6 & 1.04 & 16.2 & 1.28 & 5.1 & 0.40 & 15.7 & 1.24 & 10.2 & 0.84 & 2008 \\
\hline East South Central & 1.5 & 0.40 & 1.2 & .0 .32 & 0.2 & 0.50 & 1.4 & 0.38 & 3.4 & 0.94 & 612 \\
\hline West South Central & 13.5 & 1.41 & 9.0 & 0.94 & 9.4 & 1.00 & 10.1 & 1.05 & 8.1 & 0.84 & 1593 \\
\hline Mountain & 3.3 & 0.82 & 4.3 & 1.07 & 6.3 & 1.60 & 3.6 & 0.90 & 2.5 & 0.62 & 663 \\
\hline Pacific & 18.4 & 1.26 & 24.4 & 1.67 & 27.8 & 1.90 & 19.4 & 1.33 & 13.6 & 0.93 & 2412 \\
\hline Nonmetropolitan & 14.5 & 0.67 & 8.2 & 0.38 & 5.2 & 0.24 & 4.9 & 0.23 & 23.4 & 1.08 & 3588 \\
\hline New England & 0.7 & 0.88 & 0.8 & 1.00 & 1.0 & 1.25 & 0.8 & 1.00 & 0.9 & 1.12 & 126 \\
\hline Middle Atlantic & 1.0 & 0.77 & 0.5 & 0.36 & 0.3 & 0.21 & 0.4 & 0.29 & 1.4 & 1.00 & 226 \\
\hline East North Central & 3.7 & 1.14 & 1.4 & 0.42 & 0.5 & 0.15 & 0.4 & 0.12 & 3.8 & 1.15 & 543 \\
\hline West North Central & 1.2 & 0.45 & 0.8 & 0.31 & 1.2 & 0.46 & 0.3 & 0.11 & 2.0 & 0.77 & 435 \\
\hline South Atlantic & 2.5 & 0.52 & 1.8 & 0.37 & 0.7 & 0.14 & 1.6 & 0.33 & 6.7 & 1.37 & 806 \\
\hline East South Central & 2.0 & 0.86 & 1.0 & 0.43 & 0.5 & 0.22 & 0.2 & 0.09 & 3.4 & 1.47 & 390 \\
\hline West South Central & 2.1 & 0.77 & 0.5 & 0.19 & 0.1 & 0.04 & 0.2 & 0.08 & 2.4 & 0.89 & 451 \\
\hline Mountain & 1.0 & 0.48 & 1.0 & 0.50 & 0.7 & 0.35 & 0.7 & 0.35 & 1.3 & 0.65 & 334 \\
\hline Pacific & 0.3 & 0.18 & 0.3 & 0.18 & 0.1 & 0.59 & 0.3 & 0.18 & 1.5 & 0.88 & 227 \\
\hline United States & 100.0 & & 100.0 & & 100.0 & & 100.0 & & 100.0 & & 16,565 \\
\hline
\end{tabular}

'Detail on shares may not add to 100.0 due to rounding.

${ }^{2}$ See Table1 for industries in each industry group.

${ }^{3}$ Column 1 divided by 11 .

${ }^{4}$ Column 3 divided by 11 .

${ }^{5}$ Column 5 divided by 11 .

${ }^{6}$ Column 7 divided by 11 .

${ }^{7}$ Column 9 divided by 11 .

Source: U.S. Establishment and Enterprise Microdata, U.S. Small Business Administration.

Nonregional control of nonmetropolitan-oriented, high-tech industries (at the 3-digit SIC level) clearly is evident in most of the census divisions. In six of the nine census divisions, most of the jobs in a majority of nonmetropolitan-oriented industries (location quotients greater than 1) were created by affiliates with headquarters located outside the census region (Table 5). Nonregional control of nonmetropolitan-oriented industries was particularly apparent in the "Deep South." In the East South Central census division, nonregionally-owned affiliates created over 90 percent of the jobs in five of the six nonmetropolitan-oriented industries. In the South Atlantic states, nonregional affiliates created 60 percent or more of the jobs in three of the five nonmetropolitan-oriented industries.

By contrast, in New England, over 70 percent of the new jobs in non-metropolitan-oriented, high technology industries were created by regional companies. The proximity of regional headquarters may indicate that rural high tech branch plants are affiliated with firms in the early 
Table 4

Employment Created by New Establishments in Selected Groups of Industries, by Ownership Status, Metropolitan and Nonmetropolitan Areas, 1976-1980

\begin{tabular}{|c|c|c|c|c|c|c|c|}
\hline \multirow{3}{*}{$\begin{array}{l}\text { Industry Group } \\
\text { and County Type }\end{array}$} & \multirow{2}{*}{\multicolumn{2}{|c|}{$\begin{array}{c}\text { Independent } \\
\text { Establishments }{ }^{1}\end{array}$}} & \multicolumn{4}{|c|}{ Affiliates with headquarters } & \multirow{3}{*}{$\begin{array}{c}\text { Total } \\
\text { No. } \\
\text { (Thou.) }\end{array}$} \\
\hline & & & \multicolumn{2}{|c|}{$\begin{array}{l}\text { In Census } \\
\text { Region }^{2}\end{array}$} & \multicolumn{2}{|c|}{$\begin{array}{l}\text { Outside Census } \\
\text { Region }\end{array}$} & \\
\hline & $\begin{array}{l}\text { Number } \\
\text { (Thou.) }\end{array}$ & $\begin{array}{c}\text { Share } \\
(\%)\end{array}$ & $\begin{array}{l}\text { Number } \\
\text { (Thou.) }\end{array}$ & $\begin{array}{c}\text { Share } \\
(\%)\end{array}$ & $\begin{array}{l}\text { Number } \\
\text { (Thou.) }\end{array}$ & $\begin{array}{c}\text { Share } \\
(\%)\end{array}$ & \\
\hline \multicolumn{8}{|l|}{ High Technology: } \\
\hline Metropolitan & 136 & 11.9 & 489 & 42.7 & 519 & 45.4 & 1,144 \\
\hline Nonmetropolitan & 23 & 11.8 & 58 & 29.7 & 114 & 58.5 & 195 \\
\hline \multicolumn{8}{|l|}{ Low Technology: } \\
\hline Metropolitan & 865 & 28.5 & 1,189 & 39.2 & 979 & 32.3 & 3,033 \\
\hline Nonmetropolitan & 189 & 20.3 & 354 & 38.0 & 388 & 41.7 & 931 \\
\hline \multicolumn{8}{|l|}{ Other Industry: } \\
\hline Metropolitan & 3,241 & 36.8 & 3,553 & 40.4 & 2,005 & 22.8 & 8,799 \\
\hline Nonmetropolitan & 1,030 & 41.8 & 1,005 & 40.8 & 427 & 17.4 & 2,462 \\
\hline
\end{tabular}

${ }^{1}$ Single-unit firms.

${ }^{2}$ Affiliates with firm headquarters located in the same Census region as the affiliate.

${ }^{3}$ Affiliates with firm headquarters outside the Census region of the affiliates.

Source: U.S. Establishment and Enterprise Microdata, U.S. Small Business Administration.

stages of their product cycles. Many computer manufacturing and software central offices, e.g., are located in the urban areas of Massachusetts and Connecticut.

\section{$\underline{\text { Key Findings }}$}

(1) New establishments in high-tech industries accounted for only about 5 percent of all jobs created by all new establishments in nonmetropolitan areas during 1976-80, compared with almost 9 percent of such jobs in metropolitan areas.

(2) Regional location quotients show that new hightech establishments were less likely to locate in nonmetropolitan than in metropolitan areas. Establishments with high research and development outlays and large numbers of managerial and technical workers were the least nonmetropolitan-oriented. Hightech activities were most concentrated in metropolitan portions of the New England, the West South Central and Pacific States.

(3) Most jobs created by new high-tech establishments in nonmetropolitan areas were controlled by nonregional corporations; less than half were so controlled in metropolitan areas.

(4) Much of the high-tech industry that is drawn to nonmetropolitan locations is dependent on natural resources, is defense-related, or labor-intensive, or is involved in noxious production.

\section{Conclusions}

Policymakers and local officials should not be overly optimistic about near term prospects that nonmetropolitan areas can attract the kind of high technology operations likely to provide high-paying jobs or improve economic linkages in their communities. High-tech firms may not be as footloose as many have been led to believe, particularly when they are in their most innovative stage of development. The analysis reported here has shown that employment created by new high-tech establishments tended to concentrate in metropolitan areas and to cluster in the New England, West South Central and Pacific census divisions during 1976-80.

The lower presence of new high-tech activities in nonmetropolitan than in metropolitan areas, especially of the more innovative (high R\&D) activities, and the higher percentage of jobs in new high-tech establishments controlled by absentee (nonregional) corporations are consistent with the product cycle theory of industrial location. High-tech firms, particularly high R\&D activities in the 


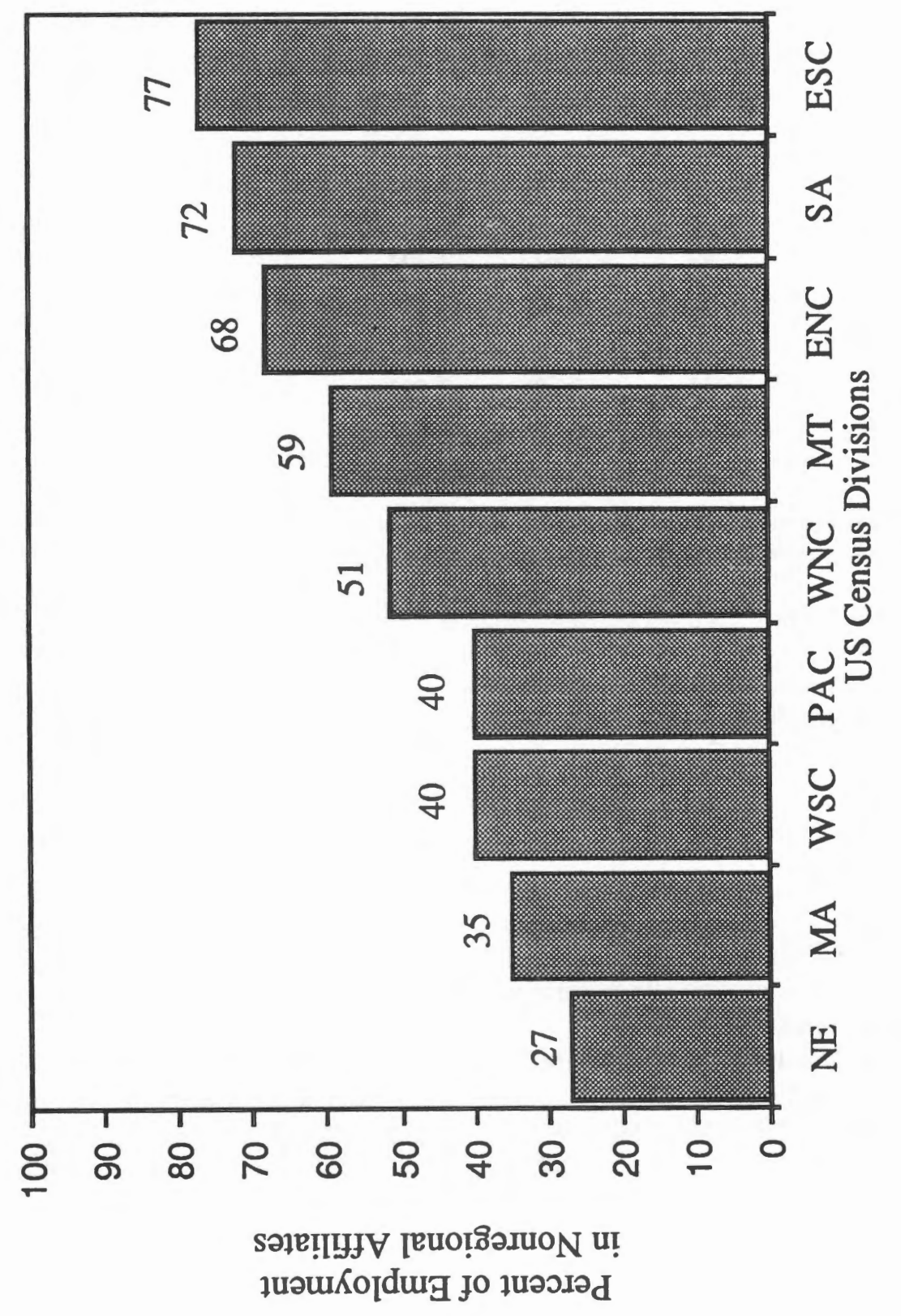


Table 5

Employment Created by New Establishments in Nonmetropolitan High Technology Industries, by Ownership Status and Census Division, Nonmetropolitan Counties, 1976-80

\begin{tabular}{|c|c|c|c|c|}
\hline \multirow{4}{*}{$\begin{array}{l}\text { Census Division } \\
\text { High Technology } \\
\text { Industry }\end{array}$} & \multirow{4}{*}{$\begin{array}{l}\text { Employment } \\
\text { Location } \\
\text { Quotient }\end{array}$} & \multicolumn{3}{|c|}{ Employment Distribution } \\
\hline & & \multirow[b]{3}{*}{ Independent $^{1}$} & \multicolumn{2}{|c|}{ Affiliates with Headquarters } \\
\hline & & & In Census & Outside Census \\
\hline & & & Region ${ }^{2}$ & Region ${ }^{3}$ \\
\hline & No. & Pct. & Pct. & Pct. \\
\hline \multicolumn{5}{|l|}{ New England } \\
\hline All High Tech Industry & 0.88 & 16 & 72 & 12 \\
\hline Engines and Turbines & 2.53 & 0 & 100 & 0 \\
\hline Office Computing Machines & 1.25 & 1 & 99 & 0 \\
\hline Electronic Components & 2.21 & 23 & 77 & 0 \\
\hline Aircraft and Parts & 2.72 & 22 & 72 & 6 \\
\hline Optical & 4.83 & 16 & 84 & 0 \\
\hline Medical Instruments/Lenses & 2.40 & 16 & 84 & 0 \\
\hline \multicolumn{5}{|l|}{ Mid Atlantic } \\
\hline All High Tech Industry & 0.77 & 15 & 50 & 35 \\
\hline Natural Gas Liquids & 1.59 & 0 & 0 & 100 \\
\hline Misc. Chemical Products & 4.69 & 9 & 85 & 6 \\
\hline Electronic Industrial Apparatus & 3.86 & 4 & 96 & 0 \\
\hline Radio and TV Equipment & 5.24 & 3 & 5 & 92 \\
\hline Medical Instruments & 1.56 & 5 & 10 & 85 \\
\hline Watches, Clocks & 1.59 & 5 & 0 & 95 \\
\hline \multicolumn{5}{|l|}{ East North Central } \\
\hline All High Tech Industry & 1.14 & 6 & 26 & 68 \\
\hline Natural Gas Liquids & 1.94 & 3 & 97 & 0 \\
\hline Plastics, Resins, Fibers & 1.33 & 8 & 37 & 55 \\
\hline Drugs & 1.13 & 9 & 1 & 90 \\
\hline Ordnance & 1.37 & 8 & 26 & 66 \\
\hline General Industrial Machinery & 6.68 & 1 & 10 & 89 \\
\hline Engineering and Scientific Equipment & 1.37 & 3 & 77 & 20 \\
\hline Watches, Clocks & 1.94 & 3 & 96 & 1 \\
\hline \multicolumn{5}{|l|}{ West North Central } \\
\hline All High Tech Industry & 0.45 & 13 & 36 & 51 \\
\hline Crude Petroleum/Natural Gas & 1.19 & 33 & 31 & 36 \\
\hline General Industrial Machinery & 1.18 & 3 & 21 & 76 \\
\hline Optical Instruments/Lenses & 1.67 & 2 & 98 & 0 \\
\hline Ophthalmic Goods & 2.01 & 5 & 0 & 95 \\
\hline \multicolumn{5}{|l|}{ South Atlantic } \\
\hline All High Tech Industry & 0.52 & 8 & 20 & 72 \\
\hline Industrial Inorganic Chemicals & 1.19 & 1 & 55 & 44 \\
\hline Plastics, Resins, Fibers & 2.33 & 1 & 14 & 85 \\
\hline Industrial Organic Chemicals & 2.96 & 3 & 34 & 63 \\
\hline Watches, Clocks & 3.52 & 0 & 0 & 100 \\
\hline
\end{tabular}


Table 5 (Continued)

\begin{tabular}{|c|c|c|c|c|}
\hline \multirow{4}{*}{$\begin{array}{c}\text { Census Division } \\
\text { High Technology } \\
\text { Industry }\end{array}$} & \multirow{4}{*}{$\begin{array}{c}\text { Employment } \\
\text { Location } \\
\text { Quotient }\end{array}$} & \multicolumn{3}{|c|}{ Employment Distribution } \\
\hline & & \multirow[b]{3}{*}{ Independent ${ }^{1}$} & \multicolumn{2}{|c|}{ Affiliates with Headquarters } \\
\hline & & & In Census & Outside Census \\
\hline & & & Region $^{2}$ & Region $^{3}$ \\
\hline & No. & Pct. & Pct. & Pct. \\
\hline \multicolumn{5}{|l|}{ East South Central } \\
\hline All High Tech Industry & 0.86 & 11 & 12 & 77 \\
\hline Plastics, Resins, Fibers & 3.48 & 39 & 39 & 22 \\
\hline Industrial Organic Chemicals & 3.28 & 2 & 6 & 92 \\
\hline Electrical Industrial Apparatus & 1.80 & 5 & 0 & 95 \\
\hline Radio and TV Equipment & 9.57 & 0 & 0 & 100 \\
\hline Communication Equipment & 1.40 & 2 & 8 & 90 \\
\hline Watches, Clocks & 1.48 & 0 & 1 & 99 \\
\hline \multicolumn{5}{|l|}{ West South Central } \\
\hline All High Tech Industry & 0.77 & 21 & 39 & 40 \\
\hline Crude Petroleum/Natural Gas & 5.12 & 33 & 35 & 32 \\
\hline Natural Gas Liquids & 4.55 & 45 & 20 & 35 \\
\hline Industrial Organic Chemicals & 2.77 & 4 & 10 & 86 \\
\hline Plastics, Resins, Fibers & 1.41 & 1 & 83 & 16 \\
\hline Misc. Chemical Products & 2.61 & 2 & 20 & 78 \\
\hline Petroleum Refining & 2.96 & 0 & 62 & 38 \\
\hline Ordnance & 6.47 & 0 & 50 & 50 \\
\hline Construction, Mining Machinery & 1.64 & 25 & 45 & 30 \\
\hline Radio and TV Equipment & 2.48 & 100 & 0 & 0 \\
\hline Engineering and Scientific Equipment & 1.98 & 0 & 91 & 9 \\
\hline \multicolumn{5}{|l|}{ Mountain } \\
\hline All High Tech Industry & 0.48 & 12 & 29 & 59 \\
\hline Crude Petroleum & 1.96 & 19 & 29 & 52 \\
\hline Ordnance & 3.56 & 3 & 0 & 97 \\
\hline Office Computing Machines & 1.94 & 13 & 38 & 49 \\
\hline Electric Components & 1.85 & 4 & 8 & 88 \\
\hline R\&D Labs & 1.67 & 5 & 54 & 41 \\
\hline \multicolumn{5}{|l|}{ Pacific } \\
\hline All High Tech Industry & 0.18 & 32 & 28 & 40 \\
\hline Industrial Organic Chemicals & 2.02 & 0 & 100 & 0 \\
\hline Optical Instruments/Lenses & 1.53 & 43 & 4 & 53 \\
\hline
\end{tabular}

${ }^{1}$ Single unit firms.

${ }^{2}$ Affiliates with firm headquarters located in the same Census region as the affiliate.

${ }^{3}$ Affiliates with firm headquarters located outsied the Census region of the affiliate.

Source: U.S. Establishment and Enterprise Microdata, U.S. Small Business Administration 
innovative and product development phase, are drawn to metropolitan locations by agglomerative advantages, notably by the availability of professional and technical workers, seed capital, close contacts with customers and suppliers and other high-tech firms. High-tech establishments in nonmetropolitan areas, on the other hand, are more likely to be affiliates of urban-based corporations that have opened routine assembly plants far from where they originated-to avoid high cost of labor, land and other production items. This often occurs after the firm has gone through an initial development stage in the "home region" and after agglomerative advantages have become less important than traditional factor input costs.

The preliminary findings presented in this report suggest that national corporations in high technology industries tend to follow the same pattern as corporations in other industries. They tend eventually to shift their routine production to nonmetropolitan areas and to regions away from the company headquarters. ${ }^{7}$ A large proportion of new high-tech jobs in nonmetropolitan areas was created during the 1976-80 period by new affiliates owned and controlled by corporate headquarters located outside the census region. Because the typical rural "high-tech" operation hires mostly unskilled, low-wage labor, it is likely to have about the same impact on the rural economy as the typical low-wage, routine manufacturing operation that has been attracted to nonmetropolitan areas in the past.

\section{Notes}

${ }^{1}$ First developed by Raymond Vernon (1966), the product cycle theory holds that products and industries go through a three-phase cycle that begins when new industries emerge with new and innovative products, continues as they expand, and ends once they saturate markets and mature. During the course of the cycle, predictable changes are supposed to occur in company organization, labor requirements, and production location. In the first stage of the cycle, firms are preoccupied with innovating and adapting products for new markets. At this stage they typically are small and independently-owned, and tend to locate in larger metropolitan areas where they can take advantage of large pools of professional and technical labor and a large market for their output. In the second stage, product standardization and mass production begins once the innovative phase is completed. The industry grows rapidly and begins to penetrate new markets. And, according to Thompson (1973), it also begins to disperse production activities to outlying locations to lower cost and capture new markets. In the third stage, industries reach maturity. By this time firms have saturated markets and begin to compete for market shares. The production process requires little of the professional and skilled labor found in metropolitan areas. The decentralization or "filtering down" of routine production activities away from the home city and region to lower-cost locations in other regions that begin in stage two is completed.

${ }^{2} \mathrm{However}$, Smith and Barkley (1988) in their survey of high-tech firms in nonmetropolitan areas in the West, also found that nonbranch activities (i.e., independent firms) provide significantly higher percentages of professional, technical and skilled jobs than branch establishments, contradicting the product cycle theory.

${ }^{3}$ Birch (1979) concludes that business start-ups and expansions reveal more about regional comparative advantage than tracking net employment change. Birch, who used Dun and Bradstreet data, shows that most of the variation in growth rates among census divisions over the 1969-76 period was due to differences in job start-up rates and expansion rates and not to variation in the rate of job loss due to closings and contractions.

"Industry data alone do not allow researchers to identify truly innovative, high-tech industries engaged in the first stage of product development. Creative entrepreneurs, the most important factor in innovation frequently are excluded from the definition of innovative workers. Scientists, engineers and computer specialists are found primarily on the payrolls of corporate firms. Sveikauskas (1979), however, points out that the inclusion of $R \& D$ expenditures improves the classification procedure.

"Not all "new client firms" were, in fact, new establishment formations between 1976 and 1980. Some, though not a large proportion by best recent estimates, were older firms that were in existence prior to 1976 and were added to Dun and Bradstreet files as new customers of the credit rating service in the 1976-80 period.

'Employment location quotients also have well-known limitations. They do not take into account labor productivity differences among areas; that is, it is possible that a relatively small proportion of the total work force in an area may be employed in a highly productive industry that markets most of its products outside the area. They also do not take into account variation among areas in the local consumption of products or services. And, perhaps of even greater significance, aggregation of employment into broad industry categories and county groups conceal many activities that are exported almost totally.

${ }^{7}$ Additional analysis, however, is need to determine whether (and to what extent) the more heavily populated nonmetropolitan counties that are adjacent to the larger metropolitan counties are attracting the more sophisticated high R\&D, high-tech activities. Smith and Barkley (1988) found that not all high-tech firms in rural counties conform to the product cycle theory. They discovered that high-tech firms in the West, if they were independently owned and operated, tended to be relatively sophisticated in their professional and skilled labor requirements and in the amount of effort they devote to research and development. 


\section{References}

Armington, C., C. Harris and M. Odle. "Formation and Growth in High Technology Business: A Regional Assessment," Business Microdata Project, The Brookings Institution, Washington D.C., Sept. 1983.

Barkley, D. L. "The Decentralization of High Technology Manufacturers to Nonmetropolitan Areas," Growth and Change, Vol 19, No. 1, Winter, 1988, pp. 13-29.

Birch, D. L. The Job Generation Process. Cambridge, Mass.: MIT Program on Neighborhood and Regional Change, 1979.

Burgan, J. U. "Cyclical Behavior of High Tech Industries" Monthly Labor Review, Vol. 108, No. 5 (May, 1985), pp. 9 15.

Erickson R. A. “Nonmetropolitan Industrial Expansion: Emerging Implications for Regional Development, "The Review of Regional Studies, Vol. 6, No. 1, Spring, 1976, pp. 35-48.

Hansen, N. "The New International Division of Labor and Manufacturing Decentralization in the United States," The Review of Regional Studies. Vol.9,No. 1 (Spring, 1979), pp. 1-11.

Herzog, H.W. Jr., A. M. Schlottman and D. L. Johnson. "High Technology Jobs and Workers Mobility," Joumal of Regional Science, Vol. 26, No. 3 (Aug. 1986). pp. 445-59.

Jacobs, J. “Why TVA Failed,"New York Review of Books, Vol. 31, No. 8 (May, 1984), pp. 41-44.

Malecki, E. J. "Industrial Location and Corporate Organization in High Technology Industries, "Economic Geography, Vol. 6, No. 4 (Oct.,1985), pp. 345-69.

Markusen, A., P. Hall, and A. Glasmeier. High Tech America. Boston: Allen \& Unwin, 1986.

Massey, D. and R. Meegan. The Anatomy of Job Loss. London:
Methuen, 1982.

Park, S. O., and J. O. Wheeler. "The Filtering Down Process in Georgia: The Third Stage of the Product Life Cycle," The Professional Geographer, Vol.35,No. 1 (Feb. 1983), pp. 1831.

Rich, R. W., D. E. Hecker, and J. U. Burgan. "High Technology Today and Tomorrow: A Small Slice of the Employment Pie," Monthly Labor Review, Vol. 102, No. 1 (Nov. 1983), pp. 18-31.

Smith, S. M., and D. L. Barkley. "Labor Force Characteristics of 'High Tech' versus 'Low Tech' Manufacturing in Nonmetropolitan Counties in the West," Joumal of the Community Development Society, Vol. 19, No. 1, 1988, pp.21-36.

Suarez-Villa, L. "Manufacturing Process Cycle in the Industrialization of the United States Borderlands,"The Annuals of Regional Science, Vol. 18, No. 1 (March, 1984), pp. 1-47.

Sveikauskas, L. "Interurban Differences in the Innovative Nature of Production," Joumal of Urban Economics. Vol. 6, No. 2 (April, 1979), pp. 216-227.

Thomas, M. "Growth Pole Theory, Technological Change and Regional Growth, Regional Science Association Papers and Proceedings. Vol. 34, (1975), pp. 3-25.

Thompson, W. R. "The Economic Base of Urban Problems," Contemporary Economic Issues, edited by N. W. Chamberlain, Homewood, IIl.: Richard D. Irwin Inc., 1973.

U.S. Congress, Office of Technology Assessment. "Technology, Innovation and Regional Economic Development: Encouraging High Technology Development-Development Paper No. 2," Washington, D.C.: Supt. of Documents, 1982.

Vernon, R. "International Investment and International Trade in the Product Cycle,"Quarterly Joumal of Economics. Vol. 80 (1966), pp. 190-207. Areas, 1976-80. 